\title{
Political Violence and Terrorism in Southeast Asia
}

\author{
An Interview with Arabinda Acharya
}

The Journal sat down with Arabinda Acharya to discuss his recent book, Whither Southeast Asian Terrorism? (Imperial College Press, 2015), which examines the origin and evolution of terrorism in Southeast Asia.

Journal: What provided the impetus for your recent book entitled Whither Southeast Asian Terrorism? What issues and trends called for an updated examination of terrorism in Southeast Asia?

Acharya: This book is the outcome of my more than twelve years of work in Southeast Asia before I came to the United States. I have also worked in India and conducted extensive research in countries like Pakistan, Bangladesh, Nepal, and Sri Lanka, and in other Central Asian countries, as well as in China. I came to Southeast Asia in 2002almost eight months after 9/11. I joined the International Centre for Political Violence and Terrorism Research in Singapore. Then, the 2002 Bali bombings happened in Indonesia. I have studied almost all the major attacks in South, Central, and Southeast Asia as well as in various European countries.

However, this book is not a handbook on terrorist groups or their leaders, attacks, tactics, and targets. In this book, I look at the conflicts in Southeast Asia broadly and those leading to political violence and terrorism particularly. I also look at counterterrorism measures by individual countries and the region as a whole, as well as the role of extra-regional powers like the United States.

This book focuses on what I perceived to be a number of myths or misperceptions about terrorism in Southeast Asia. First, there was the labeling of the region as the "second front" in the global war on terror, even though almost all of the conflicts in the 
region predated 9/11. Second, there were concerns that a number of Southeast Asian countries, especially those with a predominately Muslim population, could fall prey to religious extremism. This led to discourses like militant Islam in Southeast Asia or even the Talibanization of Southeast Asia. Third, the capability of some of these countries to deal with terrorism was suspect. Many of the countries were initially in denial mode regarding the existence of terrorism within their borders and were not interested in investing in security capabilities or networking with other countries to deal with the threat.

More than ten years after the October 2002 Bali bombings, I found that if we look at how most countries in the world have dealt with Islamist terrorism, Southeast Asian countries could be considered among the most effective. The number of terrorist-related incidents is now low. In addition, countries in the region have managed to handle terrorism not only with kinetic means, including the use of military force and kill and capture strategies, but also with non-kinetic initiatives, which I will discuss later in the interview. Most significantly, the link between the groups in Southeast Asia, particularly Jemaah Islamiyah and al-Qaeda Central, has weakened significantly. This is critical, as the regional groups had looked to al-Qaeda for inspiration, strategic direction, training, logistics, and money.

Additionally, I wanted to put in perspective how the conflicts in the region in general and terrorist threats in particular could be different in terms of orientation, objectives, tactics, and targets of the groups or individuals involved-both within the region and in comparison to other regions in the world. Contrary to conventional wisdom, and despite religious undertones, not all political contestations have produced violence and strife in Southeast Asia. In many cases, violence is associated with issues of political participation (Indonesia and the Philippines), communal relations (Indonesia), resource competition (Indonesia), or identity and quest for autonomy (Thailand, Indonesia, and the Philippines).

Southeast Asia was also unique in that I saw peace talks leading to negotiated settlements. One such example was Aceh in Indonesia, where a group called Free Aceh Movement had been demanding an independent Islamic state, but ultimately settled down to negotiate a settlement and join the mainstream through political means. At the time of this interview, the peace talks between the Moro Islamic Liberation Front (MILF) and the Philippines government are on track, while Thailand has begun to engage the militants in negotiations. All these highlighted the varying nature not only of the conflicts in Southeast Asia, but also the nature and the role of Islam in Southeast Asia vis-à-vis the same in other regions like the Middle East or even South Asia.

Thus, discourses like the second front, al-Qaeda brand, militant Islam, or the Talibanization of Southeast Asia are not as robust as they appear to be and could actually be rather problematic in respect to Southeast Asia. Instead, we need to look at the conflicts in Southeast Asia in their respective historical, political, and socio-cultural contexts, including the regions' legacy of colonial past and the impact of democratization. 
Journal: Do the major terrorist groups throughout the region share similar grievances and origins? What are some misconceptions regarding the origin and kind of terrorism in Southeast Asia that you seek to address in this book?

Acharya: Jemaah Islamiyah is the offshoot of Darul Islam, which was a post-independent struggle for establishing an Islamic state in Indonesia. It was not successful because Suharto, the supreme leader of Indonesia at the time, heavily put down the movement. Two leaders of Darul Islam, Abu Bakr Bashir and Abdullah Sungkar, were banished from Indonesia. They left Indonesia for Malaysia and set up Jemaah Islamiyah, which attempted to establish a pan-Islamic regional super state- a caliphate. Nobody had heard of Jemaah Islamiyah until 2001 when their plot to attack Singaporean and U.S. assets in the region was revealed, and the responsible members of the group were arrested in Singapore and Malaysia. Indonesia initially denied the existence of a group like Jemaah Islamiyah until the Bali bombings in 2002. By that time, Jemaah Islamiyah had already carried out a number of attacks in Indonesia, including the 2000 Christmas Eve bombings and more than fifty other bombings in different parts of the country.

The point I am trying to make is why Jemaah Islamiyah, which was initially trying to set up an Islamic state in Indonesia, became globalized, internationalized, and then went on to pursue a super-objective. It was mainly due to the influence of al-Qaeda. Al-Qaeda carried out numerous activities in Southeast Asia, including plans for both the USS Cole attack in December 2000 and the 9/11 attacks. Some of those who were involved in 9/11 came to United States through Malaysia. Similarly, Osama bin Laden also sent his brother-in-law, Jamal Khalifa, to the Philippines to set up a number of businesses, Islamic charities, and non-governmental organizations to get money for the local groups like the MILF and Jemaah Islamiyah, as well as for al-Qaeda. Al-Qaeda also set up training camps in the Philippines and Indonesia.

So, Southeast Asia was not and is not immune to al-Qaeda's influence. But, currently-and in contrast to the early twenty-first century-its influence has significantly declined. Moreover, many local groups like the MILF in the Philippines and most militants in Southern Thailand shun al-Qaeda. In Southern Thailand particularly, the fight is not about a global jihad, but rather about protection of a minority community's identity. This particular struggle is very interesting to study because here we are dealing with a dynamic in which a group of Muslims who are Malays are forced to live in a country that is predominately Buddhist and Thai. And, there is a heavy attempt by the government to integrate them into the Thai state. Two past examples include the 1921 Education Act and the 1939 Thai Customs Decree. The Education Act forced Muslims to attend state-run schools in which Buddhist monks taught Buddhist ethics. The Customs Decree prevented Muslims from adopting Muslim names or using the Malay dialect, even forcing them to participate in the public worship of Buddhist idols. These people are ethnic Malays who speak the Malay language, practice Islam, and dress differently. The Customs Decree dictated that these people dress and talk like Thais, and prohibited them from attending Islamic schools. These measures challenged the Muslims' identity, especially their ethno-cultural and religious identity, which led 
them to ultimately rebel against the central government. In fact, these measures transformed what were mainly sporadic protests by the local Muslims into armed resistance by organized groups.

Another dynamic that I saw has to do with the nature of attacks. For example, Indonesia has many suicide attacks, but there have been none in other Southeast Asian countries. Even though the Philippines experienced a number of attacks, the attacks were not suicide attacks. The only time there was the possibility of a suicide attack in the Philippines occurred when Indonesians were going to the Philippines to carry out attacks. This has also been the case in Thailand. This is due to the differing nature of Islam within Southeast Asia, as well as the localized orientation and agendas of the militant groups in their respective historical and cultural contexts.

Journal: Among the states in Southeast Asia, which nation's counterterrorism efforts have been the most effective and why? In your assessment, which Southeast Asian countries have successfully focused their counterterrorism strategies on tackling the root causes of terrorism, rather than its symptoms?

Acharya: There are several aspects of fighting terrorism that we must consider. One is the tactical aspect, which includes gates and guards, target hardening, and physical security measures. Second is the operational aspect, which includes killing and capturing terrorists, as well as destroying terrorists' training camps, support structures, and funding sources. Third is the strategic aspect, which, for example, refers to fighting the overall concept of the Islamic state or independence, separatism, and so on. From operational and tactical perspectives, most countries, especially Singapore, Malaysia, the Philippines and Indonesia, have done very well. They have destroyed all of the major groups and the groups' infrastructure. Singapore and Malaysia could achieve success as a result of their experience dealing with the Communist Malay insurgency and a very robust law called the Internal Security Act (a British era preventive detention instrument that allowed governments to detain militants indefinitely). The Internal Security Act is considered a successful piece of legislation to contain the terrorist threat in respective countries, even though there are some concerns that the governments have largely mitigated through strategic level initiatives like detainee rehabilitation, religious counseling, and community engagement. Indonesia's success is the result of a dynamic and professional counterterrorism force-the Detachment 88-which was set up after the 2002 Bali bombings and give financial and training support from the United States, Australia, and others.

While with the International Centre for Political Violence and Terrorism Research (ICPVTR), one of the projects I was involved in was countering radical ideology. I think the Centre is one of the first in the world to try to counter terrorists' ideology. ICPVTR supported an agency called the Religious Rehabilitation Group (RRG). RRG, a voluntary body of Muslim clerics in Singapore, took a leadership role in re-educating and rehabilitating the Jemaah Islamiyah detainees in custody. The result has been that a majority of the detainees are released without recidivism, meaning they have not gone back to terrorism. Almost 50 percent of the ICPVTR staff is Muslim 
and many are religious scholars. The staff would analyze the Islamist radical narratives, statements, and justifications for violence, and then counter terrorists' justifications with the same logic. Radicals and terrorists use perverted interpretation of Islamic concepts to justify violence. For example, the mastermind of the Bali attacks, Imam Samudra, wrote a book entitled Aku Melawan Teroris, which justified the Bali bombings using Quranic verses. My colleague at the Centre, Muhammed Haniff Hassan, responded with a book entitled, Unlicensed to Kill: Countering Imam Samudra's Justification for the Bali Bombing, which used mainstream interpretation of Quranic verses to counter the violent radical narrative. So, in Singapore, success was due not only to the legislation, but was also the result of increased soft power and community engagement in the fight against terrorism. This approach was the essence of President Obama's remarks at the Summit on Countering Violent Extremism in February of this year.

Indonesia has also focused on this counter-extremism aspect since the country faces a lot of radicalization, especially in the prisons. Indonesia has counter-radicalism programs, but the initiatives are not successful because of a lack of focus and corruption. A number of clerics or militants are in prison, including Jemaah Islamiyah leader Abu Bakr Bashir. These imprisoned individuals continue to preach via mobile phones, and thus still indoctrinate criminals and other detainees in the prisons. When a training camp was discovered in Aceh in 2010, a majority of those arrested were ex-detainees. Thus, these individuals had been detained, released, and returned to militancy. Indonesia has created units within both the police and the military that are quite efficient in killing, capturing, and destroying the terrorist organizers. Yet, recruitment is not stopping. The threat has now refracted into multiple fronts consisting of smaller groups and individuals who are doing activities on their own. Overall, Indonesia's counterterrorism strategy has been quite effective in terms of kinetic efforts like intelligence and law enforcement operations. But, such operational successes are often neutralised by the weak legal regime, ineffectual control over prisons, and inadequate counter-ideological initiatives such as rehabilitation and community engagement.

Journal: What is your view on the debate over the importance and threat posed by organizations versus individuals? In your assessment, is it individual terrorism or terrorist organizations that still remain a serious concern for Southeast Asia?

Acharya: Now actually, no group on its own is endangering Southeast Asia, but individuals are being mobilized. The Islamic State of Iraq and Syria (ISIS) at this point in time is in the limelight as a group, but its influence is limited to mobilization of recruits to fight in Iraq and Syria. If we look at the post-9/11 security environment, it is now very difficult for a group to maintain an organization and control territory for a long time. However, individuals whom terrorist groups like ISIS have recruited from other countries and indoctrinated are currently more dangerous and will be in the future. There is widespread concern that upon their return, recruited individuals could carry out attacks in their respective home countries. Although this has not happened yet in Southeast Asia, the concern remains high.

Journal: One characteristic of Southeast Asian terrorism is the nexus between piracy 
and terrorism. How does maritime terrorism differ from our traditional understanding of terrorism? How can states respond effectively to this particular type of terrorism?

Acharya: Between 2004 and 2006, the number of piracy attacks in the Malacca Strait and in Southeast Asian waters was very high. This prompted the insurer Lloyd's of London to declare it a "war zone."The Malacca Strait is a very narrow channel, and approximately 60 percent of the cargo traveling to China or Southeast Asia goes through the Malacca Strait. So, there was a concern that a major terrorist attack could prevent transport through the strait or damage the ports. There was also a huge concern at that time about maritime terrorism, which is when the so-called nexus between piracy and terrorism came up. However, I do not believe in the nexus between piracy and terrorism. Pirates are criminals. They have been in the business for centuries. And, if you look at the type of piracy attacks in Southeast Asia, most are carried out by economically marginalized local fishermen. These actors were driven by a poverty and profit motive, rather than by a political motive.

Moreover, there is little understanding about the difference between "maritime capabilities" of terrorist groups and their "maritime terrorist capabilities." Given the archipelagic nature of Southeast Asia, numerous groups and organizations have maritime capabilities and assets, but they use these mostly for logistical purpose like transport of goods and people. The Abu Sayyaf group, Jemaah Islamiyah, and the MILF all have boats for transportation purposes, and the Free Aceh movement was believed to have engaged in acts of piracy. Yet, carrying out a terrorist attack is a different issue and requires different capabilities. One would need maritime terrorist capabilities, such as what the Liberation Tigers of Tamil Eelam (LTTE) in Sri Lanka possessed. The LTTE had a state of the art maritime terrorist organization. Its maritime unit-Sea Tigers - was equipped with attack crafts, patrol boats, suicide boats, and submersibles with a wide array of ammunitions, including floating mines and limpet mines for maritime use. With these assets and trained personnel, the LTTE was successful in destroying a large number of Sri Lankan naval vessels and had effective sea control over waters off of Jaffna in Sri Lanka's northeast. A1-Qaeda did have maritime capabilities, but was using land capabilities against maritime targets like the USS Cole bombings. These kinds of attacks only differ from land attacks in that explosives are on a boat instead of, say, a vehicle. So, in Southeast Asia the whole concept of a nexus between terrorists and pirates was actually overblown.

Journal: Southeast Asia as a region has generally focused on ad-hoc, issue-specific cooperation in response to the increasing threat of terrorism. However, you argue that the rise of transnational terrorism necessitates increased regional collaboration. What factors have hampered cooperative efforts to combat terrorism in Southeast Asia? For example, what role do regional norms and values, such as a strong belief in non-interference and absolute state sovereignty, play in counterterrorism efforts?

Acharya: Let me give a brief introduction to cooperation in Southeast Asia. There are two multilateral security frameworks in the international system: collective security and cooperative security. Collective security is the kind of action we see in multilateral 
institutions like North Atlantic Treaty Organization (NATO) or the United Nations. There is also cooperative security, which takes into account local norms and culture. Collective security is based on military-centric initiatives, whereas cooperative security is based on military plus normative aspects. Southeast Asia is very amenable to cooperative security, but they are also sensitive to sovereignty and non-intervention norms. The whole concept of the Association of Southeast Asian Nations (ASEAN) includes the "ASEAN way of doing things." The ASEAN way emphasizes consultation, non-interference, and accepting local norms, among others. ASEAN has been quite successful in managing disputes within the region without engaging in the use of force. So there is enough synergy among the countries to deal with these issues in a cooperative manner.

However, sometimes the cooperative elements themselves are an issue. For example, the 2007 ASEAN Convention on Counterterrorism is weak because, due to concerns over sovereignty and the non-interference mindset, the states did not reach a consensus regarding the definition of terrorism. Instead, they proposed to use definitions from a number of other international conventions and treaties, which have often been mutually exclusive. This is problematic because countries are not obliged to cooperate on an activity if it falls under a convention that the country has not ratified. As a result, instead of cooperating in a holistic manner, ASEAN countries often pursue bilateral cooperation, trilateral cooperation, or sub-regional cooperation, as well as extra-regional cooperation with countries like the United States, Australia, the European Union, Japan, and India. So, Southeast Asian nations recognize that cooperation is necessary, but do not necessarily view cooperation as surrendering sovereignty. Instead, they cooperate according to the so-called ASEAN way, which stresses consensus and informality rather than formal or binding procedures. Informality is the cornerstone of cooperation in Southeast Asia, but this method can occasionally be a challenge.

Journal: In your opinion, what is the role of the United States in Southeast Asia's counterterrorism efforts? How would you assess the current Obama administration's approach to terrorism in Southeast Asia? What recommendations do you have for future U.S. administrations seeking a strategy to combat Southeast Asian terrorism?

Acharya: We cannot talk about Obama administration's approach without talking about the same by President Bush. By the time the Obama administration came to the White House, the Bush administration had already put in place numerous cooperative initiatives-both multilaterally and bilaterally-with Southeast Asian countries, including engaging with the Philippines against the Abu Sayyaf group (even though U.S. forces were not allowed to fight directly). Due to the presence of U.S. Special Forces, the Abu Sayyaf group is very weak today. The United States is also engaging similarly with Thailand and Malaysia, even though Malaysia was initially very hostile to U.S. policies. The United States has intensified its engagement with Indonesia, particularly following the October 2002 Bali bombings. So, the United States is definitely heavily engaged in Southeast Asia. In terms of building capabilities for countries to fight terrorism, the United States has done a lot and countries have generally accepted it. In fact, U.S. counterterrorism engagement in Southeast Asia may have produced much 
better outcomes than in other regions, particularly the Middle East and South Asia. But, that does not mean this cooperation has translated into enduring relationships or a very high degree of acceptance of Washington's policies. Southeast Asian countries want some leadership from the United States, but not too much because this raises issues related to sovereignty and non-interference. Also, the United States has preferred to deal with countries bilaterally, rather than through multilateral institutions. The United States has engaged with ASEAN and other initiatives such as the East Asia Summit, but its engagement is not necessarily very intrusive. Instead, the United States has granted non-NATO ally status to the Philippines and Thailand, and has pursued other bilateral initiatives with Indonesia and Singapore. In this way, the United States deals with willing allies based on mutual interests in a bilateral manner, rather than creating a framework that holistically engages these countries together.

From my perspective, this is acceptable as long as it works. This strategy takes care of each individual country's sensitivities. However, working with countries bilaterally may also be a waste of resources because the United States provides training and funds for each nation through its numerous agencies and organizations, which often overlap. It may be that the United States finds it more acceptable or more effective to provide training on an individual country basis. But, I would say that ultimately the United States should keep Southeast Asian countries together, as well as conserve and optimize resources, which are the major benefits of cooperation.

Though economic ties with Southeast Asia remain a priority from a U.S. perspective, an equally important focus for Washington is to strengthen its long-term counterterrorism policies and strategies, especially since a number of high-profile attacks and attempts against the United States have been linked to the region in the past. Overall, for Washington, maintaining a desirable balance in the region serves its diverse strategic objectives, which include securing energy resources, controlling commercial and military activities in the Indian Ocean Region and the Pacific, as well as fighting terrorists in the region-especially those that are hostile to U.S. interests.

Arabinda Acharya teaches international security affairs at the National Defense University and is the Editor of Counter Terrorist Trends and Analysis. Previously, he was Research Fellow and Head of Strategic Projects at the International Centre for Political Violence and Terrorism Research in the S. Rajaratnam School of International Studies at Nanyang Technological University, Singapore. The views expressed in this interview are his own, and do not necessarily reflect those of the respective institutions.

Arabinda Acharya was interviewed by Alex Rued and Mengjia Wan on March 17, 2015. 